\title{
Considering Biological Sex in Traumatic Brain Injury
}

\section{Anat Biegon * \\ Department of Radiology and Neurology, Stony Brook University School of Medicine, Stony Brook, NY, United States}

Published epidemiological studies of traumatic brain injury (TBI) of all severities consistently report higher incidence in men. Recent increases in the participation of women in sports and active military service as well as increasing awareness of the very large number of women who sustain but do not report TBI as a result of intimate partner violence (IPV) suggest that the number of women with TBI is significantly larger than previously believed. Women are also grossly under-represented in clinical and natural history studies of $\mathrm{TBI}$, most of which include relatively small numbers of women, ignore the role of sex- and age-related gonadal hormone levels, and report conflicting results. The emerging picture from recent studies powered to detect effects of biological sex as well as age (as a surrogate of hormonal status) suggest young (i.e., premenopausal) women are more likely to die from TBI relative to men of the same age group, but this is reversed in the 6th and 7th decades of life, coinciding with postmenopausal status in women. New data from concussion studies in young male and female athletes extend this finding to mild $\mathrm{TBI}$, since female athletes who sustained mild TBI are significantly more likely to report more symptoms than males. Studies including information on gonadal hormone status at the time of injury are still too scarce and small to draw reliable conclusions, so there is an urgent need to include biological sex and gonadal hormone status in the design and analysis of future studies of TBI.

Keywords: head trauma, concussion, men, women, sex differences

\section{INTRODUCTION}

Traumatic brain injury is a major cause of death and disability, especially among young people, and a major public health problem throughout the world. Epidemiological studies of TBI, mostly relying on emergency department and hospitalization records, consistently report higher incidence in men (1-4), sometimes explained by the higher propensity of men to be involved in physical altercations, military service and contact sports. However, this contention may need to be revised in view of recent publications suggesting that millions of women are exposed to TBI or repeated concussions caused by intimate partner violence (IPV), which are often unreported and undetected $(5,6)$. Similarly, in most observational and clinical studies of TBI, women represent $\sim 30 \%$ or less of subjects (Tables 1, 2). Consequently, the natural history, outcome and pathophysiology of TBI in women in general, and IPV victims in particular, have received little systematic investigation to date. Investigation of TBI and concussion outcome in women is also complicated by the fact that during their life time, women undergo massive and abrupt changes in gonadal hormone secretion at puberty and menopause, and are exposed to fluctuating levels of the same hormone across the menstrual cycle during their reproductive years. 
Female and male gonadal hormones are known to exert many diverse effects on brain structure and function [reviewed in (39)] which are likely to modulate the brain response to trauma in multiple ways and may, in principle, offer sex-specific treatment targets. This is an important and timely question since with the increasing involvement of women in the military (40) and in sports, including contact sports such as Rugby (41); the number of women at risk for sustaining TBI or concussion is on the rise, while treatment algorithms are still based on the results of clinical studies with an overwhelming majority of men $(70 \%$ or above), none of which resulted in an FDA approved treatment for the neurological sequelae of TBI; despite promising results from animal studies (Table 1). A comprehensive literature review of sex differences in human TBI and animal models has been published recently (42), with 73 papers demonstrating better TBI outcome in men relative to women, 41 papers which show the opposite (women better than men), 28 papers reporting no difference and 14 papers reporting mixed results. Obviously, these results are not conducive to understanding female-specific risks and attributes of TBI. The reasons for the discrepancy between human and animal studies have been addressed by us and others and are outside the scope of this minireview $(42,43)$.

Another emerging issue related to effects of biological sex on outcome of TBI is the recent recognition of the devastating longterm sequelae of repeated concussive TBIs (44), most notably chronic traumatic encephalopathy, a condition discovered and initially studied exclusively in male athletes (45).

Here we offer a concise critical review of emerging data on the effect of biological sex and hormonal status on TBI incidence and outcome, highlighting some possible mechanisms

TABLE 1 | Key clinical trials in TBI.

\begin{tabular}{lcll}
\hline References & \%women & Outcome & $\begin{array}{l}\text { Analysis } \\
\text { by Sex }\end{array}$ \\
\hline Young et al. (7) & 21 & 3-month GOS & No \\
Marshall et al. (8) & 24 & 6-month GOS & No \\
Marmarou et al. (9) & 29 & 3-month GOS & No \\
Morris et al. (10) & 23 & 6-month GOS & No \\
Clifton et al. (11) & NR & 6- month GOS & NR \\
Maas et al. (12) & 18.6 & 6-month GOS & No \\
McCarthy et al. (13) & 26 & 3-24 month GOS & No \\
Giacino et al. (14) & 27 & 4-6 week DRS & No \\
Zafonte et a. (15) & 25 & 3 months GOS & No \\
Skolnick et al. (16) & 21 & 6-month GOS & No \\
Wright et al. (17) & 26 & 6-month GOS-E & Yes (M > \\
Nichol et al. (18) & 16 & 6-month GOS-E & No \\
CRASH-3 collaborators (19) & 19 & 4-week mortality & No \\
Rowell et al. (20) & 26 & 6-month GOS-E & No \\
\hline
\end{tabular}

GOS, Glasgow outcome scale; DRS, disability rating scale; GOS-E, Glasgow coma scale, extended. NR, not reported. $M$, men; F, women. $M>F$ better outcome in men. *Trend, $p=0.07$.

Only phase III trials including $>300$ subjects are included.

None of these studies was analyzed for a sex $x$ age interaction. and identifying significant knowledge gaps which need to be filled in order to improve outcome of TBI.

\section{TBI INCIDENCE AND PREVALENCE IN MEN AND WOMEN}

Traumatic brain injury is a major public health concern and prominent cause of death and disability. Worldwide, in 2016, there were $\sim 27$ million new cases of TBI with an age-adjusted incidence rate of 369 per 100,000-representing a 3.6\% increase from 1990. In the same year, prevalence was 55.5 million individuals, representing an $8.4 \%$ increase from 1990 (46). In the US, TBI statistics published by the Centers for Disease Control and Prevention $(1-3,47)$ show that the combined rates for TBIrelated emergency department (ED) visits, hospitalizations, and deaths in the United States have been on the rise and totaled 823.7 per 100,000 US population in 2010. Furthermore, an estimated cumulative 5.3 million individuals are living with a TBI-related disability in the United States. This represents a prevalence of $\sim 2 \%$ of the U.S. population (47).

Epidemiological studies consistently report higher incidence in men, such that the odds of sustaining a TBI are 2.22 times higher in men than in women (4). The reported TBI prevalence in the general population is $16.7 \%$ among males and $8.5 \%$ among females. Overall, males account for $\sim 59 \%$ of all reported TBIrelated medical visits in the United States (48). This robust and consistent sex difference is sometimes explained by the higher propensity of men to be involved in physical altercations, military service, and contact sports (4). Sex differences in TBI incidence are modulated by age, and recent reports show that among the elderly (over 65), overall TBI incidence (49) and rates of ED visits for mild TBI were higher for women than for men (50). Similarly, rates of sports related injuries in young women seem to be equal or higher to those of men [e.g., (51-54), Table 3].

Importantly, studies relying on reported injuries and ED visits likely paint a distorted picture of the actual incidence of TBI, since they do not include TBIs suffered by female victims of intimate partner violence (IPV). IPV is a highly gendered behavior, such that the majority of perpetrators are men and the majority of victims are women, and TBIs suffered in this context are often unreported $(79,80)$. The Centers for Disease Control and Prevention (81) report that 32 million women in the United States have experienced IPV during their lifetime. Moreover, the National Intimate Partner and Sexual Violence Survey states that nearly one in four women in the United States have experienced severe physical violence (being hit, kicked, choked, beaten, burned, stabbed, or shot) during their lifetime by an intimate partner (82). Many of these violent attacks are likely to result in traumatic or anoxic brain injury, since it is common for abusers to target the victim's face, neck, and head $(83,84)$, with the prevalence of IPV-related TBI estimated as 60 to $90 \%(79,85)$. A recent study found that more than $80 \%$ of IPV victims referred from homeless or domestic violence shelters sustained multiple TBIs, $84 \%$ had clinically significant symptoms, yet only $21 \%$ sought medical attention at the time of injury (85). This very low rate reflects the fact that many battered women 
TABLE 2 | Representative observational studies of moderate and severe TBI biomarkers and outcomes.

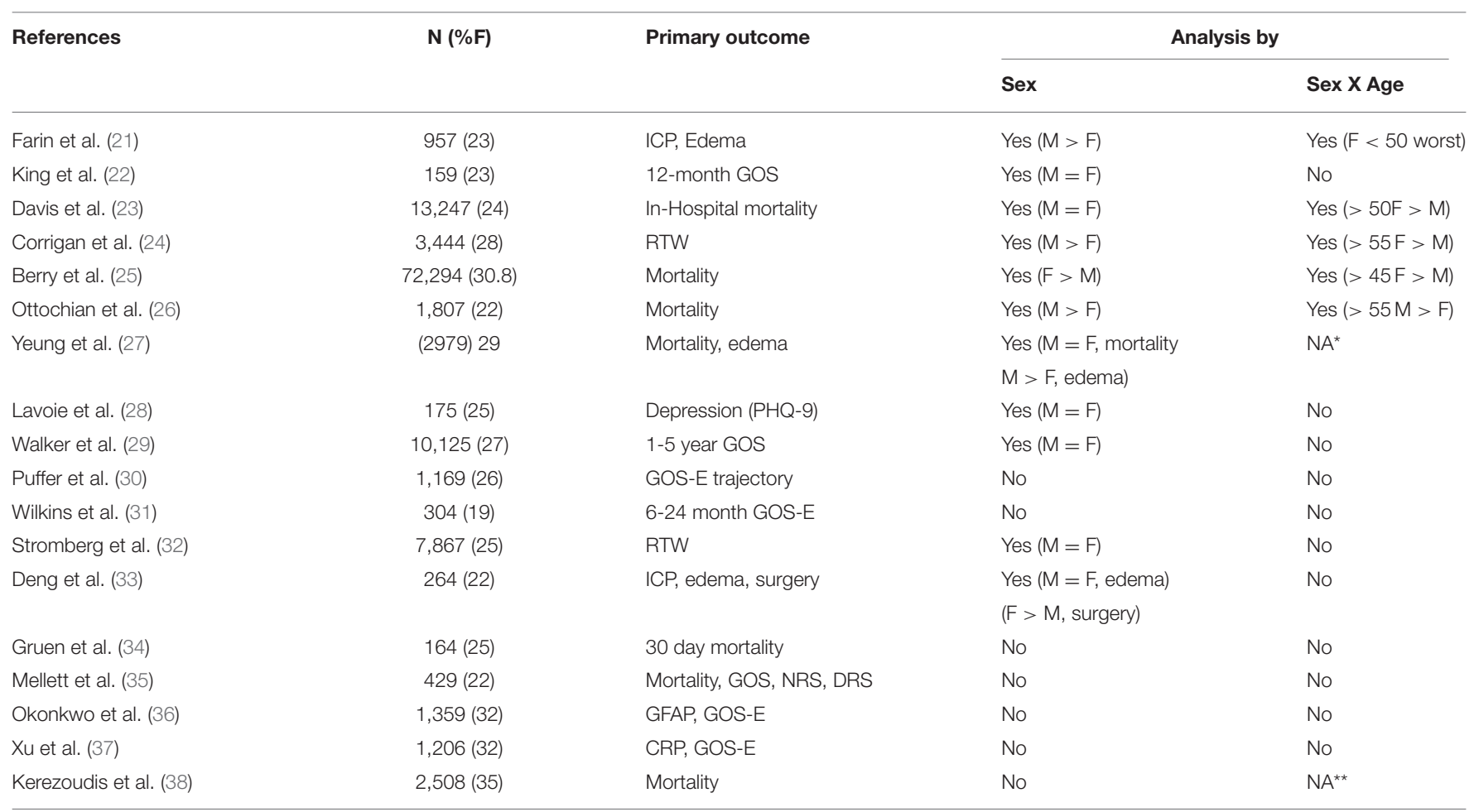

ICP, intracranial pressure; GOS, Glasgow outcome scale; RTW, return to work; GOS-E, Glasgow coma scale, extended; NRS, Neurobehavioral rating scale; DRS, disability rating scale, GFAP, Glial Fibrillary acidic protein; CRP, c-reactive protein.

NA, not applicable, "Study only included young women ${ }^{*}$ All participants were elderly.

may never go to the Emergency Department or get treated by health care providers (86-89) resulting in underreporting and poor detection. Given the numbers of women over the age of 15 experiencing IPV, there could be more than 31,000,000 women who have received a traumatic brain injury (90) in the US today- a number which should radically change our perception of TBI demographics.

\section{BIOLOGICAL SEX AND TBI OUTCOME}

TBI outcome is highly variable: Moderate and severe injuries may result in death, persistent vegetative state, severe disability, moderate disability, or good recovery, which form the basis for the most commonly used TBI outcome scales-initially the 5 step Glasgow outcome scale, (GOS), more recently replaced by the 8 step extended GOS (GOS-E). Mild TBI and concussion, which actually account for the majority ( $75 \%)$ of TBI cases (2), rarely result in death or severe disability but are often associated with long term changes in cognition and behavior $(91,92)$, which can be assessed by scales such as the Rivermeade post-concussion questionnaire [RPQ, $(22,93)$ ]. Early studies which established risk factors for poor outcome in TBI, such as advancing age (94) did not report analyses by sex.

The influence of biological sex on the outcome of TBI has been the subject of several analyses with contradictory results, possibly due to the relatively small number of women and girls in clinical studies, lack of information on hormonal status and the wide disparity in outcome measures used for the comparison, which included such disparate measures as return to work, bacteremia and mortality [(42); Tables 1, 2]. Thus, studies comparing men and women without paying attention to hormonal status or age report no differences in outcome, better outcome in women or better outcome in men $(27,95-99)$. Probably for the same reason, the recognition of various risk factors for poor TBI outcome, including advanced age, is biased toward men, and this has not changes since age as a risk factor for poor TBI outcome was first reported by Teasdale et al. (94). Consequently the treatment guidelines for head injury [e.g., $(100,101)]$ are heavily influenced by findings in male patients. Differences between the sexes in the frequencies of risk factors and their effect on early and late outcome as measured by TBI-specific outcome scales (i.e., GOS and GOSE) have not been systematically investigated to date. Similarly, research on mild TBI and concussion, which actually account for the majority ( $\sim 75 \%$ ) of TBI cases (2) in the general population is also plagued by small studies, disparate outcome measures and paucity of women (see Table 3). Understandably, mild TBI/concussion is more highly prevalent among athletes and the military $(102,103)$. While studies focusing on contact sports in which women are not represented $(91,104,105)$ do not contribute to the question at hand, there is a recent explosion of publications on sex differences in incidence and outcome of sports related concussions in sports in which women do engage (Table 3). These studies include a higher proportion of women relative to clinical and observational studies moderate-severe 
TABLE 3 | Representative studies of mild TBI and sports concussion incidence and outcomes.

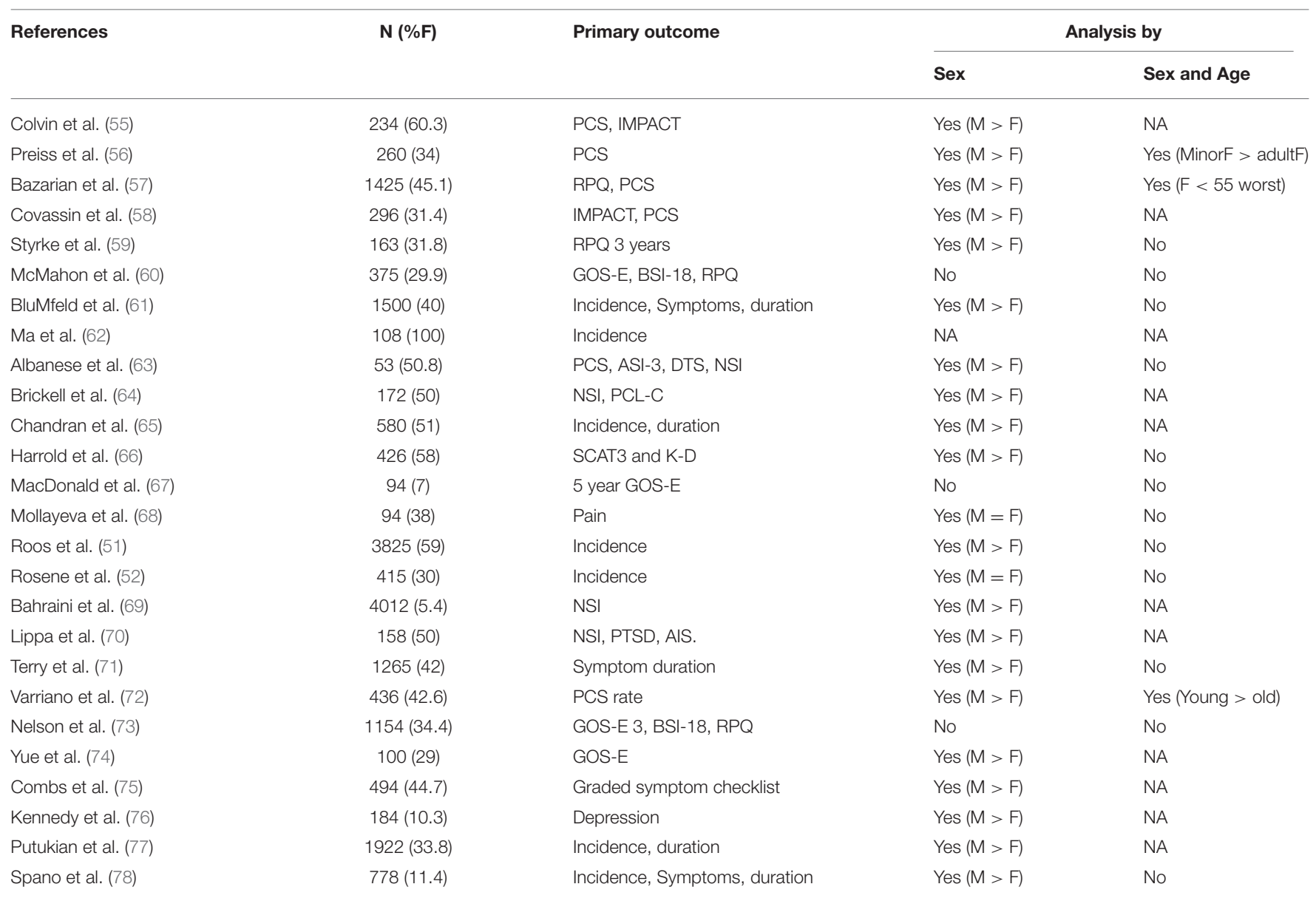

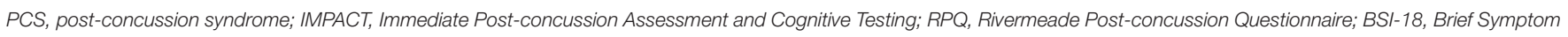

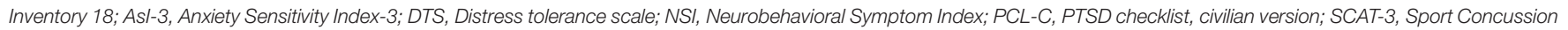
Assessment Tool 3; K-D, King-Devick scale; GSC, Graded symptom checklist.

NA, not applicable, all participants were young.

TBI (Tables 1, 2) and despite the wide range of sports included, from water polo through rugby to Jio-Jistsu, and the very large variation in outcome measures (Table 3), there appears to be a near consensus that women are more likely to receive concussions in sports and have a worse outcome. However, these studies cannot be generalized to the population at large since they typically include only young healthy subjects engaging in sports (Table 3).

\section{Biological Sex, Age and TBI-Related Mortality}

The picture is somewhat less confusing if we focus our attention on relatively large ( $\mathrm{N} \geq 1000$ total) studies reporting "hard," completely objective outcome measures such as mortality and persistent vegetative state which segregate outcome by both age and sex. An early example is the community study published by Klauber et al. (95), which reported no effect of sex on mortality. However, upon perusal of the breakdown of mortality data by sex as well as age (in decades), The results show that between puberty and old age, there is no significant effect of age on mortality in women, while mortality in men shows a strong and highly significant association with increasing age, as would be expected from prior studies (94). This sex $\mathrm{x}$ age interaction on the outcome of TBI results in a reversal of a sex difference in TBI mortality, which occurs around age 50, thereby negating an overall effect of sex on outcome. Thus, between the ages of fifteen and fifty, men have a (small) mortality advantage over women in the same age groups, but this is reversed after age fifty, when men are significantly more likely to die relative to younger men or women in all age groups. This pattern emerged in the absence of sex differences in injury severity (95). Assuming age is a reasonable surrogate for hormonal status in the absence of actual data, age 15 and over may be considered to be post pubertal and women over 50 may be considered to be mostly post-menopausal. This age cutoff is commonly used to separate mostly pre- and mostly postmenopausal female patients because the majority of women reach menopause during the decade between 45 and 55 years of age $(106,107)$, whereas in men a continuous decline in testosterone levels is associated with ages $>50$ years $(108)$. 
In a subsequent study involving 25,300 emergency headrelated admissions, it was found that women were more likely to die from all head injuries $(\mathrm{OR}=1.3)$ with an even higher likelihood of death from violent head injuries $(\mathrm{OR}=2.38)$. The authors also note that women 15 or older stayed in the hospital longer than men (109).

Davis et al. (23) published a study of a total of 13,437 patients ( $n=3,178$ females and 10,259 males) with moderateto-severe TBI (head AIS $>$ or $=3$ ) from a county trauma registry. While overall mortality was similar in men and women, a separate analysis performed for premenopausal ( $<50$ years) vs. postmenopausal ( $>$ or $=50$ years) patients, after stratification by decade of life, revealed no statistically significant difference in mortality of pre-menopausal females vs. males, though outcome was significantly better in postmenopausal females vs. males (OR $0.63,95 \% \mathrm{CI}$ ) with similar rates of hypotension (Systolic blood pressure $<90 \mathrm{~mm} \mathrm{Hg}$ ), head Abbreviated Injury Score (AIS), and Injury Severity Score (ISS). Stratification by decade of life revealed the gender survival differential inflection point to occur between ages 40-49 (OR 1.06, 95\% CI 0.66-1.71, $p=0.798$ ) and ages $50-59$ (OR $0.38,95 \%$ CI $0.20-0.74, p=0.005$ ). The authors then conclude that endogenous female sex hormone production is not neuroprotective in human TBI. These results also dovetail with those of studies performed more recently $(25,27)$. Berry et al. (25) examined records of 72,294 moderate and severe injury patients from the National Trauma Database (2000-2005) and found that peri- and postmenopausal women (Age more than 45) demonstrated improved survival relative to men, but premenopausal women did not. The exception to this trend is the (relatively modestly sized) study by Ottochian et al. (26); which included 1,800 subjects ( $22 \%$ women) and reported a survival advantage for men over 55 relative to women over 55 . The study by Yeung et al. (27), which included women under 45 , reported no survival advantage in "hormonally active" women as compared to men in the same age range. Consequently, authors of both papers concur that estrogen does not appear to confer neuroprotection in women after TBI.

\section{Sex Differences in Mild TBI/Concussion Outcome}

Sex differences in concussion incidence and outcome were reviewed by Dick (110) who concluded that the literature supports higher incidence and worse outcome in women. A later review (111) opined the literature reviewed did not support this conclusion. Table 3 features representative subsequent studies, a few of which stratified data by sex as well as age. Thus, in a 2010 study, Bazarian et al. (57) examined mTBI outcome in 1425 mTBI patients ( $45.1 \%$ female) presenting to an academic emergency department. Men were significantly less likely to be in a higher Post concussive symptoms (PCS) score category relative to women $(\mathrm{OR}=0.62)$, and this association was more prominent during child-bearing years (between puberty and menopause) for females. The authors conclude that female sex is associated with significantly higher odds of poor outcome after mTBI, as measured by PCS score, after control for appropriate confounders. This conclusion resonates with the results of a 2009 study (56) reporting no sex difference in post-concussion symptoms among minors (presumably mostly pre-pubertal subjects) with worse outcome in adult women (Table 3). This study did not include women older than 50. This is common in many of the more recently published studies on concussion in men and women performed in athletes engaged in a variety of sports and in military personnel, and therefore including a relatively young population (Table 3 ). With this caveat in mind, there appears to be a near-consensus that across different sports, women are more likely than men to suffer sports-related concussions, report more symptoms, have a slower recovery and overall more negative outcome. The latter observations were also reported in an exquisitely designed study focusing on female service members (64), whereby women $(N=86)$ reported more symptoms despite having been matched with the male comparison group $(N=$ 86) for TBI severity, mechanism of injury, bodily injury severity, days post-injury, age, number of deployments, theater where wounded, branch of service, and rank. A pilot publication on 100 subjects with mTBI (29\% women) from the TRACK TBI study examined PTSD as an outcome and concluded that sex may interact with age for PTSD symptomatology, with females 30-39 y at highest risk (74). The authors conclude that prevention and rehabilitation/counseling strategies after mTBI should likely be tailored for age and sex. Rather disappointingly, larger studies published using TRACK-TBI data, while including a similar percentage of women, did not use sex as a grouping variable in the analysis of outcomes $[(60,73)$, Table 3].

\section{Neurodegenerative Disease Following Single or Repeated TBI in Men and Women}

Traumatic brain injury is believed to be an important risk factor for neurodegenerative diseases, such as Alzheimer's disease $(\mathrm{AD})$ and chronic traumatic encephalopathy (CTE) $(112,113)$. Despite the fact that $\mathrm{AD}$ incidence and prevalence is significantly higher in women relative to men, and significant sex differences in the disease trajectory and response to treatment (114-116), there is no information on whether the $\mathrm{AD}$ risk associated with $\mathrm{TBI}$ is modulated by biological sex.

Chronic traumatic encephalopathy (CTE), a dementia-like syndrome which manifests at younger ages than $\mathrm{AD}$, appears to be linked to repeated exposure to Mild TBIs/concussions rather than a single TBI and is associated with an anatomically distinct pattern of tau deposition in the absence of significant amyloid deposits $(105,117)$. This condition was initially characterized and subsequently studied exclusively in male athletes and military personnel (44, 45, 118-120). Consequently, there are no reports on TBI-related CTE in women since the modern definition of this entity. Tantalizingly, the only description of CTElike brain pathology in a woman is a case study published by Roberts et al. (121) titled "Dementia in a punch-drunk wife," describing a woman who died following prolonged and severe IPV. 


\section{POSSIBLE MECHANISMS UNDERLYING SEX DIFFERENCES IN TBI OUTCOME}

The mechanisms underlying the relatively poor outcome of young women with TBI and concussion are not known, though several suggestions have been made based on small studies in mild TBI. Thus, Albanese et al. (63) propose that higher anxiety sensitivity mediates gender differences in post concussive symptoms, and another study cites higher preinjury migraine rates in women as a reason for longer time to return to school and sports among concussed female athletes (71). Attempts to use a similar approach regarding depression yielded conflicting results $(28,76)$. Yue et al. (74), summarizing results from the TRACK-TBI pilot, make the general observation that the sex differences they observe "may be attributable to cortical maturation, biological response, social modifiers, and/or differential self-report" although suspected sex differences in the latter variable have not been consistent when examined in the athlete population $(122,123)$. In addition, Alsalaheen et al. (124) and Grafton et al. (125) invokes different strategies to stabilize the head in response to impulsive loads as a possible explanation for sex differences in concussion injury risk. Recent studies also suggest sex differences in biomechanics of concussion in sports (126). However, these studies usually report higher impacts in males and it is hard to see how these findings can explain the consistent findings of worse outcome in women.

\section{Effects of Gonadal Steroid Levels}

Both female and male gonadal hormones are known to exert multiple diverse effects on brain structure and function; which can be roughly divided into irreversible (organizational) effects during brain development and reversible (activational) effects after puberty [reviewed in (39)]. Numerous, though not all, animal studies suggested that female sex hormones improve brain injury outcome [Reviewed in $(42,127)]$. These animal studies led to a series of clinical trials of progesterone in human TBI, however the pivotal phase III trials failed to provide any evidence of improvement in outcome [(16), Table 1]. This was the only human study in which gonadal steroid levels were manipulated through hormone administration in men and women. Interestingly, the studies were not designed to examine outcome by sex. In a study of the relationship between endogenous progesterone levels and menstrual cycle phase in women (128), the authors found that women injured during the luteal phase of their menstrual cycle, when progesterone concentration is high, had significantly lower General Health Ratings and higher RPQ somatic scores one month after injury than women injured during the follicular phase of their cycle, suggesting that high ambient levels of female gonadal steroids have a negative rather than a positive effect on mTBI outcome. In a similar vein, estradiol was identified as a "potent mortality marker," with strong relationships between increased serum E2 levels and elevated mortality risk after severe TBI reported by Wagner et al. (129). NB, the study populations was mostly male and results were not analyzed be sex.

\section{Sex Differences in Brain Volume}

Total intracranial volume has been shown to be an independent predictor of the effect of TBI on intelligence, in accordance with the cognitive reserve theory (130). In a similar vein, Ystad et al. (131) reported a highly significant correlation between hippocampal volume and performance of a verbal memory (CVLT) task, and Umile et al. (132) confirmed the vulnerability of the medial temporal lobe to mild TBI, which correlated with neuropsychological deficits. A recent study of cognitive outcome in TBI demonstrated a significant declines (relative to individual premorbid intelligence) in abstract reasoning as measured by Raven's progressive matrices- $\mathrm{R}$ (RPM- $\mathrm{R}$ ) in moderate-severe as well as mild TBI (133). In this study, there was a highly significant correlation between the volume of the insula and deficits in RPM-R performance. These studies did not report data from women.

Sex differences in intracranial volume, brain size and regional size, are found from birth and are thought to reflect organizational effects of gonadal steroids which occur during fetal brain development. On average, men have a larger brain size than women as denoted by a higher intracranial volume (ICV) and total brain volume ( $\sim 8-15 \%$ larger volumes in men), higher tissue/region-specific volume (134), a greater amount of neurons, increased global cortical thickness and larger total cortical surface area relative to women (135-137). In a more recent article which compared 58 young women and 44 young men, Martinez et al. showed ICV and total brain volume were highly significantly smaller in women relative to men $(t=8.22, p<0.00005$ and $t=$ $7.61, p<0.00005$, respectively). Importantly, the size of the sex difference in regional brain volumes diminishes with advancing age (138).

A similar sex $\mathrm{X}$ age interaction was observed in several regional studies: In an early study focusing on the corpus callosum (139), the cross sectional area of the corpus callosum and splenium was measured off a midsagittal MRI image from subjects with Alzhemier's disease (AD), age matched elderly controls, and young controls. Analysis of the healthy control data by sex and age shows reduction in callosal area with age in men which is not observed in women, resulting in a reversal of the sex difference seen in young controls (men $>$ women) when the comparison is performed in elderly subjects (Women $>$ men). In another study focusing on hippocampal volume, analysis of the healthy control population in the ADNI data base (115) showed that hippocampal volume (mean(STD) 7175 (886) $\mathrm{mm}^{3} \mathrm{~N}=187$ women vs. $7539(935) \mathrm{mm}^{3}, N=192$ men) is slightly $(5 \%)$ but significantly $(p<0.0001)$ higher in elderly men relative to women, while the sex difference in intracranial volume was $12.7 \%$ [mean $1423 \mathrm{cc}$ in women and 1604 in men, (115)]. These results dovetail with long-standing evidence of earlier and steeper age-related declines in brain regional volumes in men relative to women (140-142) which has also been confirmed for the hippocampus. For example, in a study of hippocampal volume in early adulthood [ 39 men and 41 women, age 18-42 years, (143)], a significant negative correlation with age for both left and right hippocampus was found in men ( $r=-0.47$ and -0.44 , respectively) but not in women $(r=0.01$ and 0.02 , respectively). The volume decline in men appeared to 
be linear, starting at the beginning of the third life decade and $\sim 1.5 \%$ per annum.

Investigations of moderate and severe TBI have demonstrated significant brain atrophy over the first year after injury in many brain regions, even those that are remote from direct injury, including the cingulate gyrus and the hippocampus (144-148). As in most other studies of TBI, the number of women included in these rather small studies did not support analysis of a sex $\mathrm{x}$ age interaction. To elaborate, the Schonberger (147) study included 74 men and 24 women, mostly under 50, and the Zhou study (148) examined 27 men and only 5 women.

Taken together, the sex $\mathrm{x}$ age interaction on TBI outcome and brain volumes described above supports the notion that women, possibly due to their smaller total and regional brain size (smaller brain reserve), have a worse outcome of moderate-severe as well as mild TBI/concussion compared to men; but this difference may be diminished or even reversed with advancing age since brain reserve is diminished at a steeper rate in men relative to women.

\section{Sex and Age Differences in Brain Swelling}

The well-documented effects of female gonadal hormones on fluid balance (149-151) and the high frequency of idiopathic intracranial hypertension in premenopausal female patients (152, 153) supports the likelihood of differences between the sexes in frequencies of brain swelling and intracranial hypertension following TBI, specifically in presumably premenopausal women ( $<50$ years of age). Brain swelling (edema) and the resultant increase in intracranial pressure are known risk factors for poor outcome in humans as well as in animal models of TBI (154-159). If TBI-related swelling and ICP time-dose are indeed influenced by sex and hormonal status, i.e., higher in young women than in post-menopausal women, this could be another contribution to the sex $\mathrm{x}$ age interaction on outcome described above.

The Tirilizad study was one of the first clinical studies in TBI to include outcome, CT and intracranial pressure data indicative of brain swelling in a study population large and diverse enough to enable statistically powered comparisons of brain swelling between young and $>50$ male and female patients with moderate/severe head injury $(8,21)$. Overall, female patients had a significantly greater frequency of brain swelling visualized on $\mathrm{CT}$ than male patients $-35 \%$ compared with $24 \%(p=0.0008)$. This increased frequency was characteristic of premenopausal women ( $<51$ years of age), who had a $38 \%$ rate of swelling compared with $24 \%$ among their male counterparts $(p=0.002)$, which did not change with age (21). The frequency in postmenopausal female patients ( $>50$ years of age) was comparable to the frequency in men. Subsequent analysis showed that the increased frequency of brain swelling in female patients was not due to higher injury severity or other confounders including advanced age, presence of subarachnoid hemorrhage (SAH), or systemic hypotension. Further analysis of the relationship between intracranial hypertension (defined as an ICP $>20 \mathrm{~mm} \mathrm{Hg}$ during $>25 \%$ of the time it was monitored) and sex demonstrated a significantly greater frequency of intracranial hypertension among female compared with male patients $(39 \%$ compared with $31 \%$; $p<0.03)$. The sex-related difference in frequency was even more dramatic in the population $<50$ years ( $40 \%$ compared with $30 \%$; $p<0.02$ ). The increased frequency of intracranial hypertension in women and girls was not due to increased injury severity. As was the case with brain edema, the difference in rates of intracranial hypertension between the sexes was most significant among the less severely injured patients (GCS scores of 7 or 8 [33\% compared with $20 \%$; $p<0.02]$ ) (21).

The findings from the Tirilizad study were corroborated in a more recent international study of TBI, showing that brain edema was associated with female sex $(P=0.02)$, and the odds of brain edema in females were greater than for males in a cohort of young subjects recruited in Hong Kong (27). The second cohort included in this study, recruited in Australia, demonstrated a smaller sex difference in the same direction which did not reach statistical significance. This study recruited subjects in the age range $12-45$ so that only premenopausal females were included.

\section{SUMMARY AND CONCLUSIONS}

Research conducted in the last couple of decades has significantly improved our understanding of the impact of biological sex on TBI incidence and outcome. However, some glaring still exist due to the slow and incomplete acceptance of the imperative to include women in TBI studies and report results stratified by sex, which need to be proactively addressed in the future.

\section{Key Findings}

- There is increasing recognition of the high prevalence of TBI among the tens of millions of women who live with domestic violence and fail to report- or seek medical attention fortheir injuries.

- Recent studies of TBI outcome which include adequate numbers of women challenge the long held view (based on animal studies) that reproductive-age women, by virtue of high levels of estrogen and progesterone, are likely to have a better TBI outcome relative to men.

- Accumulating evidence shows that reproductively competent women (after puberty and before menopause) are at higher risk for poor outcome, while postmenopausal women fare better than men of similar age ( $>50$ years old), whose outcome worsen with age.

\section{Knowledge Gaps}

- While recent findings suggest an important contribution of gonadal hormone levels to clinical outcome of TBI of all severities, these variables are not assessed or measured in the overwhelming majority of TBI studies.

- The safety and efficacy of old and new TBI interventions in women across the life span is unknown

- The importance of risk factors for poor outcome of TBI, established in mostly-male populations, is largely unknown in women

\section{Next Steps}

- Female subjects with TBI need to be proactively sought out and recruited from domestic violence shelters and agencies. 
- Results of clinical and research studies on TBI need to be stratified by sex and gonadal hormone status.

- Female TBI victims need to be queried about their hormonal status, i.e., Pre- or post-pubertal, pre- or post-menopausal and if reproductively competent, estimated stage of menstrual cycle (last menstrual period).

- Both men and women can benefit from actual acute and repeated measurement of sex steroid levels, including

\section{REFERENCES}

1. Centers for Disease Control and Prevention. Report to Congress on Mild Traumatic Brain Injury in the United States: Steps to Prevent a Serious Public Health Problem. Atlanta, GA: National Center for Injury Prevention and Control. (2003). Available online: https://www.cdc.gov/ traumaticbraininjury/pdf/mtbireport-a.pdf

2. Centers for Disease Control and Prevention. Traumatic Brain Injury in the United States: Fact sheet. (2014). www.cdc.gov/traumaticbraininjury/get the facts.html.

3. Centers for Disease Control and Prevention. Surveillance Report of Traumatic Brain Injury-Related Emergency Department Visits, Hospitalizations, Deaths-United States. 2014. Atlanta, GA. (2019). Available online at: https://stacks.cdc.gov/view/cdc/78062

4. Frost RB, Farrer TJ, Primosch M, Hedges DW. Prevalence of traumatic brain injury in the general adult population: a meta-analysis. Neuroepidemiology. (2013) 40:154-9. doi: 10.1159/000343275

5. Centers for Disease Control and Prevention. Adverse health conditions and health risk behaviors associated with intimate partner violence. Morb Mortal Weekly Rep. (2008) 57:113-7.

6. Monahan K, Goldfine A, Biegon A. Traumatic brain injuries in victims of intimate partner violence: an underappreciated source of neurological morbidity. Fut Neurol. (2017) 12:189-91. doi: 10.2217/fnl-2017-0026

7. Young B, Runge JW, Waxman KS, Harrington T, Wilberger J, Muizelaar JP, et al. Effects of pegorgotein on neurologic outcome of patients with severe head injury. JAMA. (1996) 276:583-5434.

8. Marshall LF, Maas AI, Marshall SB, Bricolo A, Fearnside M, Klauber MR, et al. A multicenter trial on the efficacy of using tirilazad mesylate in cases of head injury. J Neurosurg. (1998) 89:519-25. doi: 10.3171/jns.1998.89.4.0519

9. Marmarou A, Nichols J, Burgess J, Newell D, Troha J, Burnhame D, et al. Effects of the bradykinin antagonist Bradycor (deltibant, CP-1027) in severe traumatic brain injury: results of a multi-center, randomized, placebo-controlledtrial. American Brain Injury Consortium Study Group. J. Neurotrauma. (1999) 16:431-44. doi: 10.1089/neu.1999.16.431

10. Morris GF, Bullock R, Marshall SB, Marmarou A, Maas A, Marshall LF. Failure of the competitive N-methyl-D-aspartate antagonist Selfotel (CGS 19755) in the treatment of severe head injury: results of two-phase III clinical trials. The Selfotel Investigators. J. Neurosurg. (1999) 91:73743. doi: 10.3171/jns.1999.91.5.0737

11. Clifton GL, Miller ER, Choi SC, Levin HS, McCauley S, Smith Jr KR, et al. Lack of effect of hypothermia in acute brain injury. N Engl J Med. (2001) 344:556-63. doi: 10.1056/NEJM200102223440803

12. Maas A, Murray G, Henney III H, Kassem N, Legrand V, Mangelus M, et al. Efficacy and safety of dexanabinol in severe traumatic brain injury: results of a phase III randomized, placebo-controlled, clinical trial. Lancet Neurol. (2005) 5:38-45. doi: 10.1016/S1474-4422(05)70253-2

13. McCarthy MC, Moncrief H, Sands JM, Markert RJ, Hall LC, Wenker IC, et al. Neurologic outcomes with cerebral oxygen monitoring in traumatic brain injury. Surgery. (2009) 146:585-91. doi: 10.1016/j.surg.2009.06.059

14. Giacino JT, Whyte J, Bagiella E, Kalmar K, Childs N, Khademi A, et al. OTR, Mercer W, Maurer-Karattup P, Dr,Rer.Nat., Sherer M. Placebo-controlled trial of amantadine for severe traumatic brain injury. N Engl J Med. (2012) 366:819-26. doi: 10.1056/NEJMoa1102609

15. Zafonte RD, Bagiella E, Ansel BM, Novack TA, Friedewald WT, Hesdorffer DC, et al. Effect of citicoline on functional and cognitive status among androgens, estrogens, progesterone, in order to understand possible sex-specific impact of TBI on reproductive health and possibly provide new sex-sensitive guidelines and sex-specific hormone-based treatment targets.

\section{AUTHOR CONTRIBUTIONS}

$\mathrm{AB}$ conceived of and wrote the paper.

patients with traumatic brain injury: Citicoline Brain Injury Treatment Trial (COBRIT). JAMA. (2012) 308:1993-2000. doi: 10.1001/jama. 2012.13256

16. Skolnick BE, Maas AI, Narayan RK, van der Hoop RG, MacAllister T, Ward JD, et al. A clinical trial of progesterone for severe traumatic brain injury. $N$ Engl J Med. (2014) 371:2467-76. doi: 10.1056/NEJMoa1411090

17. Wright DW, Yeatts SD, Silbergleit R, Palesch YY, Hertzberg VS, Frankel M, et al. Very early administration of progesterone for acute traumatic brain injury. N Engl J Med. (2014) 371:2457-66. doi: 10.1056/NEJMoa1404304

18. Nichol A, French C, Little L, Haddad S, Presneill J, Arabi $\mathrm{Y}$, et al. Erythropoietin in traumatic brain injury (EPO-TBI) a double-blind randomised controlled trial. Lancet. (2015) 386:2499-506. doi: 10.1016/S0140-6736(15)00386-4

19. CRASH-3 trial collaborators. Effects of tranexamic acid on death, disability, vascular occlusive events and other morbidities in patients with acute traumatic brain injury (CRASH-3): a randomised, placebocontrolled trial. Lancet. (2019) 394:1713-23. doi: 10.1016/S0140-6736(19) 32233-0

20. Rowell SE, Meier EN, McKnight B, Kannas D, May S, Sheehan K, et al. Effect of out-of-hospital tranexamic acid vs placebo on 6-month functional neurologic outcomes in patients with moderate or severe traumatic brain injury. JAMA. (2020). 324:961-74. doi: 10.1001/jama.2020.8958

21. Farin A, Deutsch R, Biegon A, Marshall LF. Sex-related differences in patients with severe head injury: greater susceptibility to brain swelling in female patients 50 years of age and younger. J Neurosurg. (2003) 98:326. doi: 10.3171/jns.2003.98.1.0032

22. King NS, Crawford S, Wenden FJ, Moss NE, Wade DT. The Rivermead Post Concussion Symptoms Questionnaire: a measure of symptoms commonly experienced after head injury and its reliability. J Neurol. (1995) 242:58792. doi: 10.1007/BF00868811

23. Davis DP, Douglas DJ, Smith W, Sise MJ, Vilke GM, Holbrook TL, et al. Traumatic brain injury outcomes in pre- and post-menopausal females versus age-matched males. J Neurotrauma. (2006) 23:1408. doi: 10.1089/neu.2006.23.140

24. Corrigan JD, Lineberry LA, Komaroff E, Langlois JA, Selassie AW, Wood KD. Employment after traumatic brain injury: differences between men and women. Arch Phys Med Rehabil. (2007) 88:1400-9. doi: 10.1016/j.apmr.2007.08.006

25. Berry C, Ley EJ, Tillou A, Cryer G, Margulies D, R., et al. The effect of gender on patients with moderate to severe head injuries. J Trauma. (2009) 67:950-3. doi: 10.1097/TA.0b013e3181ba3354

26. Ottochian M, Salim A, Berry C, Chan LS, Wilson MT, Margulies DR. Severe traumatic brain injury: is there a gender difference in mortality? Am J Surg. (2009) 197:155-8. doi: 10.1016/j.amjsurg.2008.09.008

27. Yeung JHH, Mikocka-Walus AA, Cameron PA, Poon WS, Ho HF, Chang A, et al. Protection from traumatic brain injury in hormonally active women vs men of a similar age: a retrospective international study. Arch Surg. (2011) 146:436-42. doi: 10.1001/archsurg.2011.46

28. Lavoie S, Sechrist S, Quach N, Ehsanian R, Duong T, Gotlib IH, et al. Depression in men and women one year following traumatic brain injury (TBI): a TBI model systems study. Front Psychol. (2017) 8:634. doi: 10.3389/fpsyg.2017.00634

29. Walker WC, Stromberg KA, Marwitz JH, Sima AP, Agyemang AA, Graham $\mathrm{KM}$, et al. Predicting long-term global outcome after traumatic brain injury: development of a practical prognostic tool using the traumatic brain 
injury model systems national database. J Neurotrauma. (2018) 35:158795. doi: 10.1089/neu.2017.5359

30. Puffer RC, Yue JK, Mesley M, Billigen JB, Sharpless J, Fetzick AL, et al. Recovery trajectories and long-term outcomes in traumatic brain injury: a secondary analysis of the phase 3 citicoline brain injury treatment clinical trial. World Neurosurg. (2019) 125:e909-e15. doi: 10.1016/j.wneu.2019.01.207

31. Wilkins TE, Beers SR, Borrasso AJ, Brooks J, Mesley M, Puffer $\mathrm{R}$, et al. Favorable functional recovery in severe traumatic brain injury survivors beyond six months. J Neurotr. (2019) 36:3158-63. doi: 10.1089/neu.2018.6153

32. Stromberg KA, Agyemang AA, Graham KM, Walker WC, Sima AP, Marwitz $\mathrm{JH}$, et al. Using decision tree methodology to predict employment after moderate to severe traumatic brain injury. J Head Trauma Rehab. (2019) 34:E64-74. doi: 10.1097/HTR.0000000000000438

33. Deng H, Zusman BE, Nwachuku EL, Yue JK, Chang YF, Conley YP, et al. B-Cell lymphoma $2(\mathrm{Bcl}-2)$ gene is associated with intracranial hypertension after severe traumatic brain injury. J Neurotrauma. (2020). doi: 10.1089/neu.2020.7028

34. Gruen DS, Guyette FX, Brown JB, Okonkwo DO, Puccio AM, Campwala IK, et al. Association of prehospital plasma with survival in patients with traumatic brain injury: a secondary analysis of the PAMPer cluster randomized clinical trial. JAMA Netw Open. (2020) 3:e2016869. doi: 10.1001/jamanetworkopen.2020. 16869

35. Mellett K, Ren D, Alexander S, Osier N, Beers SR, Okonkwo DO, et al. Genetic variation in the TP53 gene and patient outcomes following severe traumatic brain injury. Biol Res Nurs. (2020) 22:33440. doi: 10.1177/1099800420912335

36. Okonkwo DO, Puffer RC, Puccio AM, Yuh EL, Yue JK, Diaz-Arrastia $\mathrm{R}$, et al. Point-of-Care platform blood biomarker testing of glial fibrillary acidic protein versus S100 calcium-binding protein B for prediction of traumatic brain injuries: a transforming research and clinical knowledge in traumatic brain injury study. J Neurotrauma. (2020) 37:24607. doi: $10.1089 /$ neu.2020.7140

37. Xu L, Yue JK, Korley FK, Puccio AM, Yuh EL, Sun X, et al. High-sensitivity C-reactive protein is a prognostic biomarker of 6- month disability after traumatic brain injury: results from the TRACK-TBI study. J Neurotrauma. (2020) 71:1-41. doi: 10.1089/neu.2020.7177

38. Kerezoudis P, Goyal A, Puffer RC, Parney IF, Meyer FB, Bydon M. Morbidity and mortality in elderly patients undergoing evacuation of acute traumatic subdural hematoma. Neurosurg Focus. (2020) 49:E22. doi: 10.3171/2020.7.FOCUS20439

39. Marrocco J, McEwen BS. Sex in the brain: hormones and sex differences. Dialogues Clin Neurosci. (2016) 18:37383. doi: 10.31887/DCNS.2016.18.4/jmarrocco

40. Street AE, Vogt D, Dutra L. A new generation of women veterans: stressors faced by women deployed to Iraq and Afghanistan. Clin Psychol Rev. (2009) 29:685-94. doi: 10.1016/j.cpr.2009.08.007

41. World Rugby. More Women Are Playing Rugby Than Ever Before. (2015). Available online at: https://www.world.rugby/news/60275

42. Gupte R, Brooks W, Vukas R, Pierce J, Harris J. Sex differences in traumatic brain injury: what we know and what we should know. J Neurotrauma. (2019) 36:3063-91. doi: 10.1089/neu.2018.6171

43. Narayan RK, Michel ME, Ansell B, Baethmann A, Biegon A, Bracken MB, et al. Clinical trials in head injury. J Neurotrauma. (2002) 19:50357. doi: $10.1089 / 089771502753754037$

44. Montenigro PH, Alosco ML, Martin BM, Daneshvar DH, Mez J, Chaisson $\mathrm{CE}$, et al. Cumulative head impact exposure predicts later-life depression, apathy, executive dysfunction, and cognitive impairment in former high school and college football players. J Neurotrauma. (2017) 34:32840. doi: $10.1089 /$ neu. 2016.4413

45. Mez J, Daneshvar DH, Kiernan PT, Abdolmohammadi B, Alvarez VE, Huber BR, et al. Clinicopathological evaluation of chronic traumatic encephalopathy in players of American football. JAMA. (2017) 318:360370. doi: $10.1001 /$ jama.2017.8334

46. Global Burden of Disease 2016 Traumatic Brain, I.njury, Spinal Cord. C.ollaborators. Global, regional, and national burden of traumatic brain injury and spinal cord injury, 1990-2016: A systematic analysis for the Global Burden of Disease Study 2016. Lancet. (2019) 18:5687. doi: 10.1016/S1474-4422(18)30415-0

47. Centers for Disease Control and Prevention. Report to Congress on Traumatic Brain Injury in the United States: Epidemiology and Rehabilitation. Atlanta, GA. (2015). Available online at: https://www.cdc.gov/traumaticbraininjury/ pdf/TBI_Report_to_Congress_Epi_and_Rehab-a.pdf

48. Faul $\mathrm{M}, \mathrm{Xu} \mathrm{L}$, Wald MM, Coronado VG. Traumatic Brain in the United States: Emergency Department Visits, Hospitalizations and Deaths, 2002-2006. Centers for Disease Control and Prevention, National Center for Injury Control and Prevention. (2010). https://www.cdc.gov/ traumaticbraininjury/pdf/blue_book.pdf

49. Gardner RC, Dams-O'Connor K, Morrissey MR, Manley GT. Geriatric traumatic brain injury: epidemiology, outcomes, knowledge gaps, future directions. J Neurotrauma. (2018) 35:889-906. doi: 10.1089/neu.2017.5371

50. Albrecht JS, Hirshon JM, McCunn M, Bechtold KT, Rao V, Simoni-Wastila $\mathrm{L}$, et al. Increased rates of mild traumatic brain injury among older adults in US emergency departments, 2009-2010. J Head Trauma Rehabil. (2016) 31:E1-7. doi: 10.1097/HTR.0000000000000190

51. Roos KG, Wasserman EB, Dalton SL, Gray A, Djoko A, Dompier TP, et al. Epidemiology of 3825 injuries sustained in six seasons of National Collegiate Athletic Association men's and women's soccer (2009/2010-2014/2015). Br J Sports Med. (2017) 51:1029-34. doi: 10.1136/bjsports-2015-095718

52. Rosene JM, Raksnis B, Silva B, Woefel T, Visich PS, Dompier TP, et al. Comparison of concussion rates between NCAA division $\mathrm{i}$ and division iii men's and women's ice hockey players. Am J Sports Med. (2017) 45:26229. doi: $10.1177 / 0363546517710005$

53. Sutton M, Chan V, Escobar M, Mollayeva T, Hu Z, Colantonio A. Neck injury comorbidity in concussion-related emergency department visits: a population-based study of sex differences across the life span. $J$ Womens Health. (2018) 28:473-82. doi: 10.1089/jwh.2018.7282

54. Zuckerman SL, Wegner AM, Roos KG, Djoko A, Dompier TP, Kerr ZY. Injuries sustained in National Collegiate Athletic Association Men's and Women's Basketball, 2009/2010-2014/2015. Br J Sports Med. (2018) 52:2618. doi: 10.1136/bjsports-2016-096005

55. Colvin AC, Mullen J, Lovell MR, West RV, Collins MW, Groh M. The role of concussion history and gender in recovery from soccer-related concussion. Am J Sports Med. (2009) 37:1699-704. doi: 10.1177/0363546509332497

56. Preiss-Farzanegan SJ, Chapman B, Wong TM, Wu J, Bazarian JJ. The relationship between gender and postconcussion symptoms after sport-related mild traumatic brain injury. PMR. (2009) 1:245-53. doi: 10.1016/j.pmrj.2009.01.011

57. Bazarian JJ, Blyth B, Mookerjee S, He H, McDermott MP. Sex differences in outcome after mild traumatic brain injury. J Neurotr. (2010) 27:52739. doi: $10.1089 /$ neu.2009.1068

58. Covassin T, Elbin RJ, Harris W, Parker T. Kontos A. The role of age and sex in symptoms, neurocognitive performance, and postural stability in athletes after concussion. Am J Sports Med. (2012) 40:130312. doi: $10.1177 / 0363546512444554$

59. Styrke J, Sojka P, Björnstig U, Bylund PO, Stålnacke BM. Sex-differences in symptoms, disability, and life satisfaction three years after mild traumatic brain injury: a population-based cohort study. J Rehabil Med. (2013) 45:74957. doi: 10.2340/16501977-1215

60. McMahon P, Hricik A, Yue JK, Puccio AM, Inoue T, Lingsma HF, et al. Symptomatology and functional outcome in mild traumatic brain injury: results from the prospective TRACK-TBI study. J Neurotrauma. (2014) 31:26-33. doi: 10.1089/neu.2013.2984

61. Blumenfeld RS, Winsell JC, Hicks JW, Small SL. The epidemiology of sportsrelated head injury and concussion in water polo. Front Neurol. (2016) 7:98. doi: 10.3389/fneur.2016.00098

62. Ma R, Lopez VJr., Weinstein, M,G, Chenm JL, Black CM, Gupta AT, et al. Injury profile of American Women's Rugby-7s. Med Sci Sports Exerc. (2016) 48:1957-66. doi: 10.1249/MSS.0000000000000997

63. Albanese BJ, Boffa JW, Macatee RJ, Schmidt NB. Anxiety sensitivity mediates gender differences in postconcussive symptoms in a clinical sample. Psychiatry Res. (2017) 252:242-6. doi: 10.1016/j.psychres.2017.01.099

64. Brickell TA, Lippa SM, French LM, Kennedy JE, Bailie JM, Lange RT. Female service members and symptom reporting after combat and 
non-combat-related mild traumatic brain injury. J Neurotrauma. (2017) 34:300-12. doi: 10.1089/neu.2016.4403

65. Chandran A, Barron MJ, Westerman BJ, DiPietro L. Multifactorial examination of sex-differences in head injuries and concussions among collegiate soccer players: NCAA ISS. 2004-2009. Inj Epidemiol. (2017) 4:28. doi: 10.1186/s40621-017-0127-6

66. Harrold KG, Hasanaj L, Moehringer N, Zhang I, Nolan R, Serrano L, et al. Rapid sideline performance meets outpatient clinic: results from a multidisciplinary concussion center registry. J Neurol Sci. (2017) 379:3127. doi: 10.1016/j.jns.2017.06.038

67. MacDonald CL, Barber J, Jordan M, Johnson AM, Dikmen S, Fann JR, et al. Early clinical predictors of 5-year outcome after concussive blast traumatic brain injury. JAMA Neurol. (2017) 74:821-9. doi: 10.1001/jamaneurol.2017.0143

68. Mollayeva T, Cassidy JD, Shapiro CM, Mollayeva S, Colantonio A. Concussion/mild traumatic brain injury-related chronic pain in males and females: a diagnostic modelling study. Medicine. (2017) 96:e5917. doi: 10.1097/MD.0000000000005917

69. Bahraini NH, Hostetter TA, Forster JE, Schneider AL, Brenner LA. A rasch analysis of the neurobehavioral symptom inventory in a national cohort of operation enduring and iraqi freedom veterans with mild traumatic brain injury. Psychol Assess. (2018) 30:1013-27. doi: 10.1037/pas0000555

70. Lippa SM, Brickell TA, Bailie JM, French LM, Kennedy JE, Lange RT. Postconcussion symptom reporting after mild traumatic brain injury in female service members: impact of gender, posttraumatic stress disorder, severity of injury, and associated bodily injuries. J Head Trauma Rehabil. (2018) 33:101-12. doi: 10.1097/HTR.0000000000000353

71. Terry DP, Huebschmann NA, Maxwell BA, Cook NE, Mannix R, Zafonte $\mathrm{R}$, et al. Preinjury migraine history as a risk factor for prolonged return to school and sports following concussion. I Neurotrauma. (2018). doi: 10.1089/neu.2017.5443

72. Varriano B, Tomlinson G, Tarazi A, Wennberg R, Tator C, Tartaglia MC. Age, gender and mechanism of injury interactions in post-concussion syndrome. Can J Neurol Sci. (2018) 45:636-42. doi: 10.1017/cjn.2018.322

73. Nelson LD, Temkin NR, Dikmen S, Barber J, Giacino JT, Yuh E, et al. Recovery after mild traumatic brain injury in patients presenting to US level I trauma centers: a transforming research and clinical knowledge in traumatic brain injury (TRACK-TBI) study. JAMA Neurol. (2019) 76:104959. doi: 10.1001/jamaneurol.2019.1313

74. Yue JK, Levin HS, Suen CG, Morrissey MR, Runyon SJ, Winkler EA, et al. Age and sex-mediated differences in six-month outcomes after mild traumatic brain injury in young adults: a TRACK-TBI study. Neurol Res. (2019) 41:609-23. doi: 10.1080/01616412.2019.1602312

75. Combs PR, Ford CB, Campbell KR, Carneiro KA, Mihalik JP. Influence of self-reported fatigue and sex on baseline concussion assessment scores. Orthop J Sports Med. (2019) 7:2325967118817515. doi: 10.1177/2325967118817515

76. Kennedy JE, Lu LH, Reid MW, Leal FO, Cooper DB. Correlates of depression in U.S. Military service members with a history of mild traumatic brain injury. Mil Med. (2019) 184:148-54. doi: 10.1093/milmed/usy321

77. Putukian M, D’Alonzo BA, Campbell-McGovern CS, Wiebe DJ. The ivy league-big ten epidemiology of concussion study: a report on methods and first findings. Am J Sports Med. (2019) 47:1236-47. doi: 10.1177/0363546519830100

78. Spano M, Risucci DA, Etienne M, Petersen KH. Epidemiology of sports related concussion in brazilian jiu-jitsu: a cross-sectional study. Sports. (2019) 7:E53. doi: 10.3390/sports7020053

79. Monahan K, O'Leary KD. Head injury and battered women: an initial inquiry. Health Soc Work. (1999) 24:269-78. doi: 10.1093/hsw/24.4.269

80. Banks ME. Overlooked but critical: traumatic brain injury as a consequence of interpersonal violence. Trauma Violence Abuse. (2007) 8:290-8. doi: 10.1177/1524838007303503

81. Black MC, Breiding MJ. Adverse and health risk behaviors associated health conditions with intimate partner violence - United States, 2005. Morb Mortal Wkly Rep. (2008) 57:113-7.

82. Black MC, Basile KC, Breiding MJ, Smith SG, Walters ML, Merrick MT, et al. The National Intimate Partner and Sexual Violence Survey (NISVS): 2010 Summary Report. Atlanta, GA: National Center for Injury
Prevention and Control, Centers for Disease Control and Prevention. (2011). Available online at: www.cdc.gov/ViolencePrevention/pdf/ NISVSExecutiveSummary703a.pdf

83. Wu V, Huff $\mathrm{H}$, Bhandari M. Pattern of physical injury associated with intimate partner violence in women presenting to the emergency department: a systematic review and meta-analysis. Trauma Violence Abuse. (2010) 11:71-82. doi: 10.1177/1524838010367503

84. Matteoli M, Piacentino D, Kotzalidis G, Serata D, Rapinesi C, Angeletti G, et al. The clinical and radiological examination of acute intimate partner violence injuries: a retrospective analysis of an italian cohort of women. Violence Vict. (2016) 31:85-102. doi: 10.1891/0886-6708.VV-D-14-00107

85. St Ivany A, Schminkey D. Intimate partner violence and traumatic brain injury: state of the science and next steps. Fam Community Health. (2016) 39:129-37. doi: 10.1097/FCH.0000000000000094

86. Barnett OW. Why battered women do not leave, Part 2. Trauma Violence Abuse. (2001) 2:3-35. doi: 10.1177/1524838001002001001

87. Stark E. Coercive Control: How Men Entrap Women in Personal Life. (2007). New York, NY: Oxford University Press.

88. Kwako LE, Glass N, Campbell J, Melvin KC, Barr T, Gill JM. Traumatic brain injury in intimate partner violence: a critical review of outcomes and mechanisms. Trauma Violence Abuse. (2011) 12:115-26. doi: 10.1177/1524838011404251

89. Policastro C, Finn MA. Coercive control and physical violence in older adults: analysis using data from the national elder mistreatment study. $J$ Interpers. Violence. (2017) 32:311-30. doi: 10.1177/0886260515585545

90. Valera EM, Campbell JC, Gill J, Iverson KM. Correlates of brain injuries in women subjected to intimate partner violence: identifying the dangers and raising awareness. J Aggress Maltreat Traum. (2019) 80:695713. doi: 10.1080/10926771.2019.1581864

91. McCrea M, Guskiewicz KM, Marshall SW, Barr W, Randolph C, Cantu $\mathrm{RC}$, et al. Acute effects and recovery time following concussion in collegiate football players. JAMA. (2003) 290:2556-63. doi: 10.1001/jama.290.19.2556

92. Marshall S, Bayley M, McCullagh S, Velikonja D, Berrigan L, Ouchterlony $\mathrm{D}$, et al. Updated clinical practice guidelines for concussion/mild traumatic brain injury and persistent symptoms. Brain Inj. (2015) 29:688700. doi: 10.3109/02699052.2015.1004755

93. Potter S, Leigh E, Wade D, Fleminger S. The Rivermead post concussion symptoms questionnaire. J Neurol. (2006) 253:1603-14. doi: 10.1007/s00415-006-0275-Z

94. Teasdale G, Skene A, Parker L, Jennett B. Age and outcome of severe head injury. Acta Neurochir Suppl. (1979) 28:140-3.

95. Klauber MR, Barrett-Connor E, Marshall LF, Bowers SA. The epidemiology of head injury: a prospective study of an entire community- San Diego County, California, 1978. Am J Epidemiol. (1981) 113:5009. doi: 10.1093/oxfordjournals.aje.a113125

96. Farace E, Alves WM. WM: Do women fare worse: a metaanalysis of gender differences in traumatic brain injury outcome. J Neuro- Surg. (2000) 93:53945. doi: 10.3171/jns.2000.93.4.0539

97. Groswasser Z, Cohen M, Keren O. Female TBI patients recover better than males. Brain Inj. (1998) 12:805-8. doi: 10.1080/026990598122197

98. Sperry JL, Nathens AB, Frankel HL, Vanek SL, Moore EE, Maier RV, et al. Inflammation and the Host Response to Injury Investigators. Characterization of the gender dimorphism after injury and hemorrhagic shock: are hormonal differences responsible? Crit Care Med. (2008) 36:183845. doi: 10.1097/CCM.0b013e3181760c14

99. Magnotti LJ, Fischer PE, Zarzaur BL, Fabian TC, Croce MA. Impact of gender on outcomes after blunt injury: a definitive analysis of more than 36,000 trauma patients. J Am Coll Surg. (2008) 206:9847. doi: 10.1016/j.jamcollsurg.2007.12.038

100. Hoogmartens O, Heselmans A, Van de Velde S, Castrén M, Sjölin H, Sabbe $M$, et al. Evidence-based prehospital management of severe traumatic brain injury: a comparative analysis of current clinical practice guidelines. Prehosp Emerg Care. (2014) 8:265-73. doi: 10.3109/10903127.2013. 856506

101. Volovici V, Steyerberg EW, Cnossen MC, Haitsma IK, Dirven CMF, Maas AIR, et al. Evolution of evidence and guideline recommendations for the medical management of severe traumatic brain injury. J Neurotrauma. (2019) 36:22. doi: 10.1089/neu.2019.6474 
102. Gessel LM, Fields SK, Collins CL, Dick RW, Comstock RD. Concussions among United States high school and collegiate athletes. J Athl Train. (2007) 42:495-503.

103. Cameron KL, Marshall SW, Sturdivant RX, Lincoln AE. Trends in the incidence of physician-diagnosed mild traumatic brain injury among active duty U.S. military personnel between 1997 and 2007. J Neurotrauma. (2012) 29:1313-21. doi: 10.1089/neu.2011.2168

104. McAllister TW, Ford JC, Flashman LA, Maerlender A, Green-wald RM, Beckwith JG, et al. Effect of head impacts on diffusivity measures in a cohort of collegiate contact sport athletes. Neurology. (2014) 82:639. doi: 10.1212/01.wnl.0000438220.16190.42

105. McKee AC, Stein TD, Kiernan PT, Alvarez VE. The neuropathology of chronic traumatic encephalopathy. Brain Pathol. (2015) 25:35064. doi: 10.1111/bpa.12248

106. Johannes CB, Crawford SL. Menstrual bleeding, hormones, and the menopausal transition. Semin Reprod Endocrinol. (1999) 17:299-309. doi: 10.1055/s-2007-1016240

107. O'Connor KA, Holman DJ, Wood JW. Menstrual cycle variability and the perimenopause. Am J Human Biol. (2001) 13:465-78. doi: 10.1002/ajhb.1078

108. Maas D, Jochen A, Lalande B. Age-related changes in male gonadal function. Implications for therapy. Drugs Aging. (1997) 11:45-60. doi: 10.2165/00002512-199711010-00005

109. Gilthorpe MS, Wilson RC, Moles DR, Bedi R. Variations in admissions to hospital for head injury and assault to the head. Part 1: Age and gender. Br J Oral Maxillofac Surg. (1999) 37:294-300. doi: 10.1054/bjom.1998.0039

110. Dick RW. Is there a gender difference in concussion incidence and outcomes? Br J Sports Med. (2009) 43:i46i50. doi: 10.1136/bjsm.2009.058172

111. Brook EM, Luo X, Curry EJ, Matzkin EG. A heads up on concussions: are there sex-related differences? Phys Sportsmed. (2016) 44:20-8. doi: 10.1080/00913847.2016.1142834

112. Edwards 3rd G, Moreno-Gonzalez I, Soto C. Amyloid-beta and tau pathology following repetitive mild traumatic brain injury. Biochem Biophys Res Commun. (2017) 483:1137-42. doi: 10.1016/j.bbrc.2016.07.123

113. Ramos-Cejudo J, Wisniewski T, Marmar C, Zetterberg $H$, Blennow K, Leon M,J., et al. Traumatic brain injury and Alzheimer's disease: the cerebrovascular link. EBioMedicine. (2018) 28:21-30. doi: 10.1016/j.ebiom.2018.01.021

114. Farlow MR, Lahiri DK, Poirier J, Davignon J, Schneider L, Hui SL. Treatment outcome of tacrine therapy depends on apolipoprotein genotype and gender of the subjects with Alzheimer's disease. Neurology. (1998) 50:669-77. doi: 10.1212/wnl.50.3.669

115. Sundermann EE, Biegon A, Rubin LH, Lipton RB, Mowrey W, Landau $S$, et al. Better verbal memory in women than men in MCI despite similar levels of hippocampal atrophy. Neurology. (2016) 86:136876. doi: 10.1212/WNL.0000000000002570

116. Sundermann EE, Maki PM, Rubin LH, Lipton RB, Landau $\mathrm{S}$, Biegon $\mathrm{A}$, et al. Female advantage in verbal memory: Evidence of sex-specific cognitive reserve. Neurology. (2016) 87:1916-24. doi: 10.1212/WNL.0000000000003288

117. Omalu BI, DeKosky ST, Minster RL, Kamboh M, I., Hamilton RL, Wecht CH. Chronic traumatic encephalopathy in a National Football League player. Neurosurgery. (2005) 57:128-34; discussion 128-134. doi: 10.1227/01.NEU.0000163407.92769.ED

118. Goldstein LE, Fisher AM, Tagge CA, Zhang X, Velisek L, Sullivan JA, et al. Chronic traumatic encephalopathy in blast-exposed military veterans and a blast neurotrauma mouse model. Sci Transl Med. (2012) 4:134ra60. doi: 10.1126/scitranslmed.3003716

119. McKee AC, Robinson ME. Military-related traumatic brain injury and neurodegeneration. Alzheimers Dement. (2014) 10:S242-53. doi: 10.1016/j.jalz.2014.04.003

120. Alosco ML, Stein TD, Tripodis Y, Chua AS, Kowall NW, Huber BR, et al. Association of white matter rarefaction, arteriolosclerosis, and tau with dementia in chronic traumatic encephalopathy. JAMA Neurol. (2019) 76:1298-308. doi: 10.1001/jamaneurol.2019.2244

121. Roberts GW, Whitwell H, Acland PR, Bruton CJ. Dementia in a punch-drunk wife. Lancet. (1990) 335:918-9. doi: 10.1016/0140-6736(90) 90520-f
122. Kroshus E, Baugh CM, Stein CJ, Austin SB, Calzo JP. Concussion reporting, sex, and conformity to traditional gender norms in young adults. J Adolesc. (2017) 54:110-9. doi: 10.1016/j.adolescence. 2016.11.002

123. Sullivan L, Molcho M. Gender differences in concussion-related knowledge, attitudes and reporting-behaviors among high school student-athletes. Int J Adolesc Med Health. (2018). doi: 10.1515/ijamh-2018-0031

124. Alsalaheen B, McCloskey K, Bean R, Almeida A, Eckner J, Lorincz M. Women and men use different strategies to stabilize the head in response to impulsive loads: implications for concussion injury risk. J Orthop Sports Phys Ther. (2019) 49:779-86. doi: 10.2519/jospt.2019.8760

125. Grafton ST, Ralston AB, Ralston JD. Monitoring of postural sway with a head-mounted wearable device: effects of gender, participant state, and concussion. Med Devices (Auckl). (2019) 12:151-64. doi: 10.2147/MDER.S205357

126. Mihalik JP, Amalfe SA, Roby PR, Ford CB, Lynall RC, Riegler $\mathrm{KE}$, et al. Sex and sport differences in college lacrosse and soccer head impact biomechanics. Med Sci Sports Exerc. (2020) 52:2349-56. doi: 10.1249/mss.0000000000002382

127. Wei J, Xiao GM. The neuroprotective effects of progesterone on traumatic brain injury: current status and future prospects. Acta Pharmacol Sin. (2013) 34:1485-90. doi: 10.1038/aps.2013.160

128. Wunderle K, Hoeger, KM, Wasserman E. Menstrual phase as predictor of outcome after mild traumatic brain injury in women. J Head Trauma Rehab. (2014) 29:E1-E8. doi: 10.1097/HTR.0000000000000006

129. Wagner AK, McCullough EH, Niyonkuru C, Ozawa H, Loucks TL, Dobos JA, et al. Acute serum hormone levels: characterization and prognosis after severe traumatic brain injury. J Neurotrauma. (2011) 28:87188. doi: 10.1089/neu.2010.1586

130. Kesler SR, Adams HF, Blasey CM, Bigler ED. Premorbid intellectual functioning, education, and brain size in traumatic brain injury: an investigation of the cognitive reserve hypothesis. Appl Neuropsychol. (2003) 10:153-62. doi: 10.1207/S15324826AN1003_04

131. Ystad MA, Lundervold AJ, Wehling E, Espeseth T, Rootwelt H, Westlye LT, et al. Hippocampal volumes are important predictors for memory function in elderly women. BMC Med Imaging. (2009) 9:17. doi: 10.1186/1471-2342-9-17

132. Umile ET, Sandel ME, Alavi A, Terry CM, Plotkin RC. Dynamic imaging in mild traumatic brain injury: support for the theory of medial temporal vulnerability. Arch Phys Med Rehab. (2002) 83:150613. doi: 10.1053/apmr.2002.35092

133. Livny A, Biegon A, Kushnir T, Harnof S, Hoffmann C, Fruchter E, et al. Cognitive deficits post-traumatic brain injury and their association with injury severity and gray matter volumes. J Neurotrauma. (2017) 34:146672. doi: $10.1089 /$ neu.2016.4598

134. Ruigrok AN, Salimi-Khorshidi G, Lai MC, Baron-Cohen S, Lombardo MV, Tait RJ, et al. A meta-analysis of sex differences in human brain structure. Neurosci Biobehav Rev. (2014) 39:34-50. doi: 10.1016/j.neubiorev.2013.12.004

135. Escorial S, Roman FJ, Martinez K, Burgaleta M, Karama S, Colom R. Sex differences in neocortical structure and cognitive performance: a surface-based morphometry study. Neuroimage. (2015) 104:355-65. doi: 10.1016/j.neuroimage.2014.09.035

136. Luders E, Gaser C, Narr KL, Toga AW. Why sex matters: brain size independent differences in gray matter distributions between men and women. J Neurosci. (2009) 29:1426570. doi: 10.1523/JNEUROSCI.2261-09.2009

137. Pakkenberg B, Gundersen HJ. Neocortical neuron number in humans: effect of sex and age. J Comp Neurol. (1997) 384:312-20.

138. Martínez K, Janssen J, Pineda-Pardo JÁ, Carmona S, Román FJ, AlemánGómez Y, et al. Individual differences in the dominance of interhemispheric connections predict cognitive ability beyond sex and brain size. Neuroimage. (2017) 155:234-44. doi: 10.1016/j.neuroimage.2017.04.029

139. Biegon A, Eberling JL, Richardson BC, Roos MS, Wong ST, Reed $\mathrm{BR}$, et al. Human corpus callosum in aging and Alzheimer's disease: a magnetic resonance imaging study. Neurobiol Aging. (1994) 15:3937. doi: 10.1016/0197-4580(94)90070-1

140. Gur RC, Mozley PD, Resnick SM, Gottlieb GL, Kohn M, Zimmerman $\mathrm{R}$, et al. Gender differences in age effect on brain atrophy measured by 
magnetic rensonace imaging. Proc Natl Acad Sci USA. (1991) 88:28459. doi: 10.1073/pnas.88.7.2845

141. Blatter DD, Bigler ED, Gale SD, Johnson SC, Anderson CV, Burnett BM, et al. Quantitative volumetric analysis of brain MR: normative database spanning 5 decades of life. Am J Neuroradiol. (1995) 16:241-51.

142. Coffey CE, Lucke JF, Saxton JA, Ratcliff G, Unitas LJ, Billig B, et al. Sex differences in brain aging: a quantitative magnetic resonance imaging study. Arch Neurol. (1998) 55:169-79. doi: 10.1001/archneur.55.2.169

143. Pruessner JC, Collins DL, Pruessner M, Evans AC. Age and gender predict volume decline in the anterior and posterior hippocampus in early adulthood. J Neurosci. (2001) 21:194200. doi: 10.1523/JNEUROSCI.21-01-00194.2001

144. Bigler ED, Blatter. D. D., Anderson CV, Johnson SV, Gale SD, Hopkins RO, et al. Hippocampal volume in normal aging and traumatic brain injury. AJNR Am J Neuroradiol. (1997) 18:11-23.

145. Yount R, Raschke KA, Biru M, Tate DF, Miller MJ, Abildskov T, et al. Traumatic brain injury and atrophy of the cingulate gyrus. J Neuropsychiatry Clin Neurosci. (2002) 14:416-23. doi: 10.1176/jnp.14.4.416

146. Levine B, Kovacevic N, Nica EI, Cheung G, Gao F, Schwartz ML, et al. The Toronto traumatic brain injury study: injury severity and quantified MRI. Neurology. (2008) 70:771-8. doi: 10.1212/01.wnl.0000304108. 32283.aa

147. Schönberger M, Ponsford J, Reutens D, Beare R, O'Sullivan R. The Relationship between age, injury severity, and MRI findings after traumatic brain injury. J Neurotrauma. (2009) 26:2157-67. doi: 10.1089/neu.2009.0939

148. Zhou Y, Kierans A, Kenul D, Ge Y, Rath J, Reaume J, et al. Mild traumatic brain injury: longitudinal regional brain volume changes. Radiology. (2013) 267:880-90. doi: 10.1148/radiol.13122542

149. Silberstein SD, Merriam GR. Physiology of the menstrual cycle. Cephalalgia. (2000) 20:148-54. doi: 10.1046/j.1468-2982.2000.00034.x

150. Stachenfeld NS, Silva C, Keefe DL, Kokoszka CA, Nadel ER. Effects of oral contraceptives on body fluid regulation. J Appl Physiol. (1999) 87:101625. doi: 10.1152/jappl.1999.87.3.1016

151. Watanabe H, Lau DC, Guyn HL, Wong NL. Effect of progesterone therapy on arginine vasopressin and atrial natriuretic factor in premenstrual syndrome. Clin Invest Med. (1997) 20:211-23.

152. Jones JS, Nevai J, Freeman MP, McNinch DE. Emergency department presentation of idiopathic intracranial hypertension.
Am J Emerg Med. (1999) 17:517-21. doi: 10.1016/s0735-6757(99) 90188-2

153. Wall M. Idiopathic intracranial hypertension: mechanisms of visual loss and disease management. Semin Neurol. (2000) 20:89-95.

154. Unterberg AW, Stover J, Kress B, Kiening KL. Edema and brain trauma. Neuroscience. (2004) 129:1021-9. doi: 10.1016/j.neuroscience

155. Alberico AM, Ward JD, Choi SC, Marmarou A, Young HF. Outcome after severe head injury: relationship to mass lesions, diffuse injury, and ICP course in pediatric and adult patients. J Neurosurg. (1987) 67:64856. doi: 10.3171/jns.1987.67.5.0648

156. Sheth KN, Stein DM, Aarabi B, Hu P, Kufera JA, Scalea TM, et al. Intracranial pressure dose and outcome in traumatic brain injury. Neurocrit Care. (2013) 18:26-32. doi: 10.1007/s12028-012-9780-3

157. Kahraman S, Dutton RP, Hu P, Xiao Y, Aarabi B, Stein DM, et al. Automated measurement of "pressure times time dose" of intracranial hypertension best predicts outcome after severe traumatic brain injury. J Trauma. (2010) 69:110-8. doi: 10.1097/TA.0b013e3181c99853

158. Yao X, Uchida K, Papadopoulos MC, Zador Z, Manley GT, Verkman AS. Mildly reduced brain swelling and improved neurological outcome in aquaporin-4 knockout mice following controlled cortical impact brain injury. J Neurotrauma. (2015) 32:1458-64. doi: 10.1089/neu.2014.3675

159. Liang F, Luo C, Xu G, Su F, He X, Long S, et al. Deletion of aquaporin4 is neuroprotective during the acute stage of micro traumatic brain injury in mice. Neurosci Lett. (2015) 598:29-35. doi: 10.1016/j.neulet. 2015.05.006

Conflict of Interest: The author declares that the research was conducted in the absence of any commercial or financial relationships that could be construed as a potential conflict of interest.

The handling editor is currently organizing a Research Topic with the author AB.

Copyright (C) 2021 Biegon. This is an open-access article distributed under the terms of the Creative Commons Attribution License (CC BY). The use, distribution or reproduction in other forums is permitted, provided the original author(s) and the copyright owner(s) are credited and that the original publication in this journal is cited, in accordance with accepted academic practice. No use, distribution or reproduction is permitted which does not comply with these terms. 